\title{
Candidiasis and demodicosis of facial skin imitating exacerbation of rosacea
}

\section{Kandydoza i nużyca skóry twarzy imitująca zaostrzenie trądziku różowatego}

\author{
Anna M. Łańczak', Maciej Spałek', Honorata Kubisiak-Rzepczyk², Dorota Jenerowicz³, \\ Monika Bowszyc-Dmochowska ${ }^{4}$, Zygmunt Adamski ${ }^{3}$
}

\author{
'Students' Scientific Association at the Department of Dermatology, Poznan University of Medical Sciences, Poznan, Poland \\ ${ }^{2}$ Section of Medical Mycology, Department of Dermatology, Poznan University of Medical Sciences, Poznan, Poland \\ ${ }^{3}$ Department of Dermatology, Poznan University of Medical Sciences, Poznan, Poland \\ ${ }^{4}$ Cutaneous Histopathology and Immunopathology Section, Department of Dermatology, Poznan University of Medical Sciences, \\ Poznan, Poland \\ 'Studenkie Koło Naukowe przy Katedrze i Klinice Dermatologii Uniwersytetu Medycznego w Poznaniu, Polska \\ ${ }^{2}$ Pracownia Mikologii Lekarskiej Katedry i Kliniki Dermatologii Uniwersytetu Medycznego w Poznaniu, Polska \\ ${ }^{3}$ Katedra i Klinika Dermatologii Uniwersytetu Medycznego w Poznaniu, Polska \\ 4Pracownia Histopatologii i Immunopatologii Skóry Katedry i Kliniki Dermatologii Uniwersytetu Medycznego w Poznaniu, Polska
}

\section{CORRESPONDING AUTHOR/} ADRES DO KORESPONDENCJI:

Anna M. Łańczak

Studenkie Koło Naukowe

Dermatologii i Wenerologii

Uniwersytet Medyczny

Szpital Kliniczny

im. Heliodora Święcickiego

ul. Przybyszewksiego 49

60-356 Poznań

tel.: +48 889787570

e-mail: anna.lanczak@gmail.com

\begin{abstract}
Rosacea is a chronic dermatosis, manifesting with erythema, papular or pustular eruptions located in the facial area. The authors present a case of an 84-year-old woman with a long-term history of rosacea who had a mycotic infection of the facial skin imitating aggravation of the underlying disease. The case presented by us can be regarded as a variant of "tinea incognito", i.e., undiagnosed mycosis, misdiagnosed as another dermatosis, which is often aggravated by the patient by using local glucocorticosteroids or other local immunomodulators, which hinders proper diagnosis. It may be diagnostically relevant to consider other comorbidities in elderly patients with rosacea.
\end{abstract}

\section{STRESZCZENIE}

Trądzik różowaty jest przewlekłą dermatozą, która objawia się występowaniem wykwitów rumieniowych, grudkowych lub krostkowych w obrębie skóry twarzy. Autorzy przedstawiają przypadek 84-letniej kobiety $\mathrm{z}$ wieloletnim wywiadem $\mathrm{w}$ kierunku trądziku różowatego, u której rozpoznano grzybicze zakażenie skóry twarzy imitujące nasilenie choroby podstawowej. Prezentowany przez nas przypadek można uznać za odmianę tinea incognito, tj. grzybicę błędnie rozpoznaną jako inna dermatoza. Przypadki tego typu często są powodowane przez samych pacjentów, którzy stosują miejscowe glikokortykosteroidy lub inne miejscowe immunomodulatory, co utrudnia właściwą diagnozę. U pacjentów $\mathrm{z}$ trądzikiem różowatym w starszym wieku możliwe jest współwystępowanie nużycy i nadkażenie innymi patogenami.

Key words: rosacea, candidiasis, demodicosis, glucocorticosteroids, tinea incognito.

Słowa kluczowe: trądzik różowaty, grzybica, nużyca, glikokortykosteroidy, tinea incognito. 


\section{INTRODUCTION}

Rosacea is a chronic dermatosis, manifesting with papules and pustules located on the erythematous base together with the formation of telangiectasias. It results in the patient feeling discomfort in the form of burning and stressed skin [1].

Rosacea is one of the most common skin diseases in the European population. It is estimated at $12.3 \%$ in the German population and $5 \%$ in the Russian population [2]. It usually refers to people with the first, second and third skin phototype according to Fitzpatrick [3]. The onset of the disease is generally at the age of 30 , and the highest occurrence of the disease is observed around 50 years of age [4]. The etiology of rosacea has not been fully elucidated. As one of the causative factors, the Demodex mite is suspected - Demodex folliculorum or Demodex brevis. It is suggested that the Demodex mite may be a vector for a microorganism exacerbating the course of rosacea - the bacterium Bacillus oleronius [5]. This bacterium was isolated for the first time in 1995 from termite guts [6] and produces proteins activating neutrophils, causing local inflammation in the perifollicular tissue [7].

On the other hand, mycosis of the glabrous skin most often affects exposed parts of the skin, such as the neck and face. Erythematous lesions are typically accompanied by scaling and ring-shaped spreading with a central clearing [8]. It is confirmed that those hormonal and vasomotor disturbances along with immunosuppression predispose to fungal infections in this location [1].

\section{OBJECTIVE}

The authors present a case of an 84-year-old woman with a long-term history of rosacea who had a mycotic infection of the facial skin imitating aggravation of the underlying disease.

\section{CASE REPORT}

The 84-year-old female patient was referred to the Department of Dermatology in Poznan, because of the asymmetrically localized scaly, erythematous plaque on the right cheek, accompanied by pruritus (fig. 1). On palpation, the lesion had significantly increased density concerning the surrounding skin. Apart from skin problems, the patient reported hypertension and hypothyroidism - she has been taking ramipril $5 \mathrm{mg}$ and levothyroxine $75 \mu \mathrm{g}$. The patient was diagnosed with papulopustular rosacea more than 5 years previously. The family history of skin diseases was negative. The patient was a farmer and was

\section{WPROWADZENIE}

Trądzik różowaty jest przewlekłą dermatozą objawiającą się występowaniem wykwitów grudkowych i krostkowych na podłożu rumieniowym, którym towarzyszą teleangiektazje. Schorzenie wywołuje dyskomfort w postaci uczucia pieczenia i napięcia skóry [1].

Trądzik różowaty jest jedną z najczęstszych chorób skóry w populacji europejskiej. Częstość występowania schorzenia szacuje się na $12,3 \% \mathrm{w}$ populacji niemieckiej i 5\% w populacji rosyjskiej [2]. Trądzik różowaty zazwyczaj rozwija się u osób z fototypem I, II lub III skóry wg klasyfikacji Fitzpatricka [3]. Początek choroby zwykle występuje w wieku 30 lat, a szczyt zachorowań przypada ok. 50. roku życia [4]. Etiologia trądziku różowatego nie została $\mathrm{w}$ pełni poznana. Przypuszcza się, że jednym z czynników sprawczych jest zakażenie nużeńcem - roztoczem z gatunku Demodex folliculorum lub Demodex brevis. Pojawiają się także sugestie, że nużeniec może być wektorem dla drobnoustroju powodującego zaostrzenie przebiegu trądziku różowatego - bakterii Bacillus oleronius [5]. Bakteria, którą wyizolowano po raz pierwszy w 1995 roku z jelit termitów [6], wytwarza białka aktywujące neutrofile, co wywołuje miejscowy stan zapalny w tkance okołomieszkowej [7].

Grzybica skóry gładkiej zajmuje najczęściej odsłonięte okolice skóry, takie jak szyja i twarz. Wykwitom rumieniowym zazwyczaj towarzyszy łuszczenie. Zmiany rozrastają się odśrodkowo, w postaci pierścieni, które wygasają w części centralnej [8]. Potwierdzono, że zakażeniom grzybiczym w tej lokalizacji sprzyjają zaburzenia hormonalne i naczynioruchowe oraz immunosupresja [1].

\section{CEL PRACY}

Autorzy przedstawiają przypadek 84-letniej kobiety z wieloletnim wywiadem trądziku różowatego, u której rozpoznano zakażenie grzybicze skóry twarzy imitujące nasilenie choroby podstawowej.

\section{OPIS PRZYPADKU}

Kobieta 84-letnia została skierowana do Kliniki Dermatologii w Poznaniu z powodu rumieniowo-złuszczającej blaszki umiejscowionej asymetrycznie na prawym policzku, której towarzyszył świąd (ryc. 1). W badaniu palpacyjnym stwierdzono wzmożoną spoistość zmiany w porównaniu z otaczającą skórą. Oprócz dolegliwości skórnych kobieta zgłaszała nadciśnienie i niedoczynność tarczycy - przyjmowała ramipryl w dawce $5 \mathrm{mg}$ i lewotyroksynę w dawce $75 \mu \mathrm{g}$. Ponad 5 lat wcześniej u pacjentki rozpoznano postać grud- 


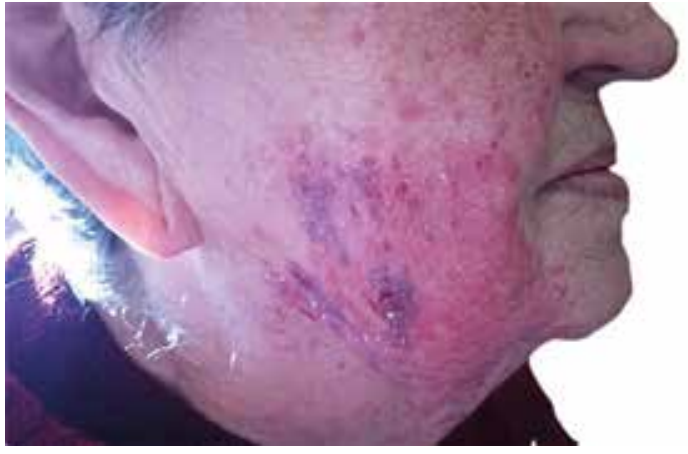

Figure I. The 84-year-old woman with an asymmetrically localized erythematous-exfoliative lesion on the right cheek

Rycina I. Pacjentka 84-letnia z rumieniowo-złuszczającą zmianą skórną umiejscowioną asymetrycznie na prawym policzku

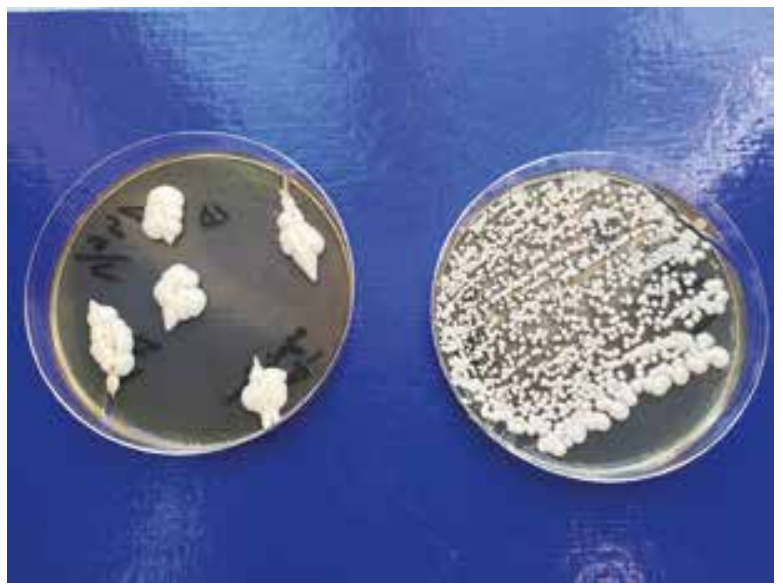

Figure 3. Culture on Sabouraud medium presents colonies of yeast-like fungi of Candida albicans

Rycina 3. Kolonie grzybów drożdżopodobnych Candida albicans w hodowli na podłożu Sabourauda

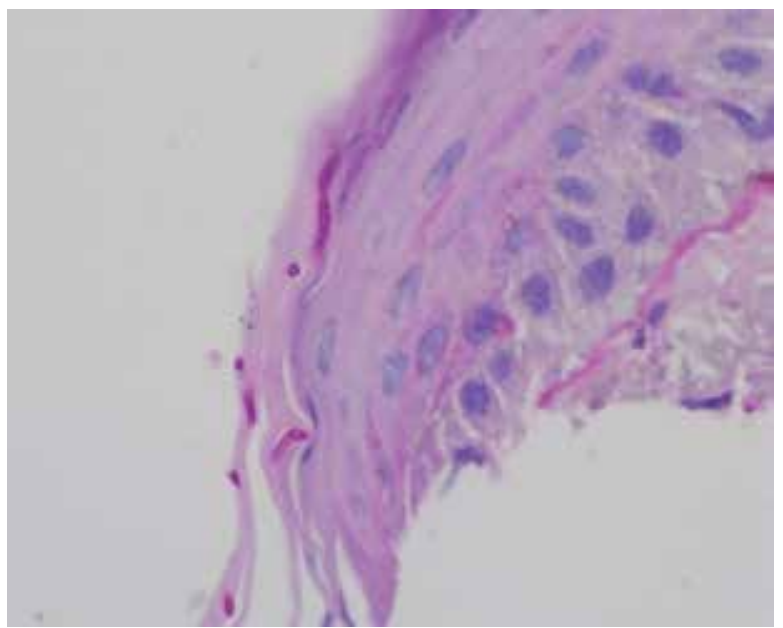

Figure 5. Fungi in the horny layer (PAS stain, objective magnification $60 \times$ )

Rycina 5. Obecność grzybów w warstwie rogowej (barwienie PAS, powiększenie $60 \times$ )

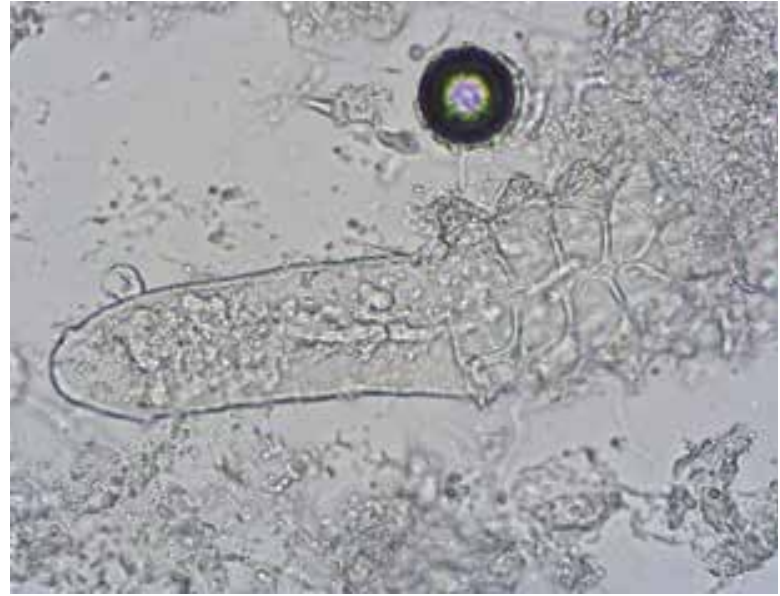

Figure 2. Direct microscopy of $10 \% \mathrm{KOH}$ solution with DMSO revealed the presence of fungal hyphae and Demodex folliculorum mite (objective magnification 60X)

Rycina 2. Strzępki grzybowe i roztocza Demodex folliculorum w bezpośrednim preparacie mikroskopowym w 10 -procentowym roztworze $\mathrm{KOH}$ z dodatkiem DMSO (powiększenie 60×)

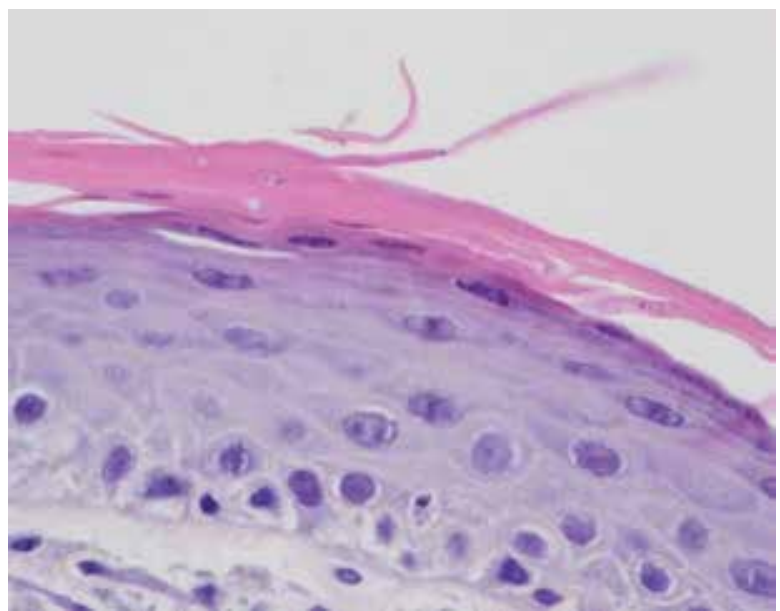

Figure 4. Fungal hyphae and spores in the horny layer $(\mathrm{H} \& \mathrm{E}$, objective magnification 60x)

Rycina 4. Strzępki i zarodniki grzybów w warstwie rogowej (barwienie $\mathrm{H}+\mathrm{E}$, powiększenie $60 \times$ )

kowo-krostkową trądziku różowatego. Wywiad rodzinny w kierunku chorób skóry był ujemny. Kobieta miała gospodarstwo rolne i zajmowała się hodowlą zwierząt. Miesiąc wcześniej zauważyła niewielką grudkę na policzku i zaczęła miejscowo stosować słabą maść glikokortykosteroidową bez konsultacji z lekarzem.

W preparacie bezpośrednim w 10-procentowym roztworze $\mathrm{KOH}$ z dodatkiem DMSO stwierdzono strzępki grzybowe i roztocza z gatunku Demodex folliculorum (ryc. 2).

$\mathrm{W}$ badaniu histopatologicznym stwierdzono ścieńczały naskórek z oznakami zaniku i obecnością rzadkich strzępek oraz zarodników grzyba 
breeding animals. A month before the patient discovered a small papule on her cheek, she started to apply a weak steroid ointment without medical consultation.

Direct preparation in $10 \% \mathrm{KOH}$ solution with DMSO revealed the presence of fungal hyphae and Demodex folliculorum mites (fig. 2).

Histopathological examination showed thin atrophic epidermis with rare fungal hyphae and spores (figs. 3, 4). Moreover, massive elastosis, as a sign of chronic sun damage, and telangiectasias were present in the upper dermis. There were only fragments of hair follicles visible in the biopsy, and Demodex mites were absent. Due to severe erythema and itching sensation, the patient was treated with isoconazole and diflucortolone cream - this time under strict dermatological supervision. After 2 weeks marked alleviation of symptoms was observed, and isoconazole solely was further used.

Culture on Sabouraud medium revealed colonies of yeast-like fungi of Candida albicans (fig. 5).

Further treatment was carried out using miconazole cream. Therapy lasted a total of 6 weeks until the lesion subsided completely. No systemic treatment was applied due to the limited extent of the lesion and the older age of the patient. Regular use of photoprotection was also recommended due to the history of rosacea and massive elastosis revealed in histopathological examination.

\section{DISCUSSION}

The case presented by us may be regarded as a variant of "tinea incognito", i.e., undiagnosed mycosis, erroneously diagnosed as another dermatosis, which is often caused by the patient using local glucocorticosteroids or other local immunomodulators, which hinders proper diagnosis [9]. These drugs inhibit the development of inflammatory reactions, which allows pathogens to develop, remaining unnoticed [10]. It is estimated that up to $70 \%$ of face mycotic infections are initially diagnosed as a different disease entity, due to imitation of the clinical picture of other dermatoses. Based on the Nicola et al. study, in which the clinical picture of 107 skin mycoses was assessed, a typical clinical picture (oval, desquamative, accompanied by pruritus) was presented by $57.1 \%$ of patients, and $42.9 \%$ were atypical [11]. The most frequent misdiagnoses of facial mycosis are usually lupus erythematosus, contact dermatitis and lymphocytic infiltration [12].

The clinical case presented by us is also interesting as, according to our knowledge, it is the first described case of the coexistence of these three disease entities: candidiasis of facial skin, rosacea, (ryc. 3, 4). Ponadto w górnej warstwie skóry występowała nasilona elastoza wskazująca na przewlekłe posłoneczne uszkodzenie skóry oraz teleangiektazje. W materiale biopsyjnym widoczne były jedynie fragmenty mieszków włosowych. Nie stwierdzono obecności nużeńca. Ze względu na silny rumień i świąd u pacjentki wdrożono leczenie izokonazolem i diflukortolonem $\mathrm{w}$ postaci kremu tym razem pod ścisłym nadzorem dermatologa. Po 2 tygodniach zaobserwowano wyraźne złagodzenie objawów. W dalszym leczeniu stosowano wyłącznie izokonazol.

W hodowli na podłożu Sabourauda uzyskano kolonie grzybów drożdżopodobnych Candida albicans (ryc. 5).

Dalszą terapię prowadzono przy zastosowaniu kremu zawierającego mikonazol. Leczenie trwało łącznie 6 tygodni, aż do całkowitego ustąpienia zmiany skórnej. Nie wdrożono leczenia ogólnoustrojowego ze względu na ograniczony zasięg wykwitu i podeszły wiek pacjentki. Zalecono również regularne stosowanie ochrony przeciwsłonecznej ze względu na trądzik różowaty $\mathrm{w}$ wywiadzie oraz nasiloną elastozę $w$ badaniu histopatologicznym.

\section{OMÓWIENIE}

Przedstawiony przypadek można uznać za odmianę tinea incognito, tj. niezdiagnozowaną grzybicę błędnie rozpoznaną jako inna dermatoza. Do jej rozwoju często przyczynia się sam pacjent, stosując miejscowe glikokortykosteroidy lub inne miejscowe immunomodulatory, co utrudnia ustalenie diagnozy [9]. Leki te hamują rozwój reakcji zapalnych, a to sprzyja niezauważonemu namnażaniu się patogenów [10]. Szacuje się, że nawet $70 \%$ zakażeń grzybiczych twarzy jest pierwotnie rozpoznawanych jako inna jednostka chorobowa ze względu na imitowanie obrazu klinicznego innych dermatoz. W badaniu Nicola i wsp., w którym przeanalizowano obraz kliniczny 107 przypadków grzybicy skóry, charakterystyczny obraz (owalne zmiany o charakterze złuszczającym, którym towarzyszył świąd) stwierdzono u 57,1\% pacjentów, natomiast u $42,9 \%$ zmiany miały obraz atypowy [11]. Grzybica twarzy jest najczęściej błędnie diagnozowana jako toczeń rumieniowaty, kontaktowe zapalenie skóry i naciek limfocytarny [12].

Przedstawiony przypadek jest ciekawy również $\mathrm{z}$ tego powodu, że według naszej wiedzy jest to pierwsze doniesienie dotyczące współistnienia trzech jednostek chorobowych: kandydozy skóry twarzy, trądziku różowatego i wtórnej nużycy. Należy podkreślić, że postać grudkowo-krostkowa trądziku różowatego i nużyca przypominająca trą- 
and secondary demodicosis. Furthermore, papulopustular rosacea and rosacea-like demodicosis have numerous similarities, and it is difficult to distinguish an entity [13].

In 1998 Daning et al. [14] published a case report of a patient presenting with a desquamative lesion on the facial skin, erythematous, with associated oral mucosal occlusion and paronychia which was identified after 6 years as an infection caused by Candida albicans. The authors of the work already emphasized the excessive use of glucocorticosteroids as the possible causative agent of the growing frequency of mycosis of the facial skin.

In the review published by Alteras et al. [15] as the most common etiologic factors of a face and skin mycosis imitating rosacea, the following are mentioned: Trichophyton rubrum and Trichophyton mentagrophytes. However, our patient developed tinea incognito with Candida albicans, which does not have such a common etiology as above but should also be taken into consideration [16].

The occurrence of "tinea incognito" in Poland is lower than in Western Europe, due to the limited access to glucocorticosteroids, which in other European countries are available in pharmacies without a prescription. However, also in our country preparations containing glucocorticosteroids are often used by patients not following medical recommendations or prescribed by doctors inadequately to be diagnosed, which only intensifies the development of infection [17].

\section{CONCLUSIONS}

Due to the similar clinical picture of various dermatoses, we should remember to confirm the diagnosis with diagnostic tests - in particular, mycological examination. It should be recognized that if there is a chronic disease of the skin, which is rosacea, and older age of the patient, it is possible to have additional demodicosis and superinfection with other pathogens - in this case, candidiasis of glabrous skin.

The etiology of rosacea is not sufficiently known and complicated, and our study confirms that.

A crucial factor that affects the course of rosacea is the education of patients, consisting in informing them about appropriate ways of skin care and avoiding factors that may lead to exacerbations (strong spices, sun, significant temperature amplitudes, alcohol) [18]. Education, both for patients and general practitioners, on the use of topical glucocorticosteroids preparations and their possible complications may also influence the course of the disease. dzik różowaty mają bardzo podobny obraz, a rozróżnienie tych jednostek sprawia trudności [13].

W 1998 roku Daning i wsp. [14] opublikowali opis przypadku, w którym umiejscowioną na twarzy zmianę złuszczającą na podłożu rumieniowym, z towarzyszącą niedrożnością błony śluzowej jamy ustnej i zanokcicą, zdiagnozowano po 6 latach jako zakażenie wywołane przez Candida albicans. Autorzy wskazali nadmierne stosowanie glikokortykosteroidów jako możliwy czynnik odpowiadający za zwiększoną częstość występowania grzybicy skóry twarzy.

W pracy przeglądowej Alteras i wsp. [15] jako najczęstsze czynniki etiologiczne grzybicy twarzy i skóry imitującej trądzik różowaty wymieniono Trichophyton rubrum i Trichophyton mentagrophytes. U naszej pacjentki wystąpiła tinea incognito wywołana przez Candida albicans, która nie jest tak rozpowszechnionym czynnikiem etiologicznym jak opisane powyżej, ale należy ją również brać pod uwage [16].

Częstość występowania tinea incognito w Polsce jest mniejsza niż w Europie Zachodniej ze względu na ograniczony dostęp do glikokortykosteroidów, które w innych krajach europejskich można kupić w aptekach bez recepty. Jednak w Polsce preparaty zawierające glikokortykosteroidy są często stosowane przez pacjentów, którzy nie przestrzegają zaleceń lekarskich, lub są przepisywane przez lekarzy niezgodnie z rozpoznaniem, co jedynie wzmaga rozwój zakażenia [17].

\section{WNIOSKI}

Ze względu na zbliżony obraz kliniczny różnych dermatoz należy pamiętać o potwierdzeniu rozpoznania za pomocą testów diagnostycznych, zwłaszcza badania mykologicznego. W sytuacji występowania choroby przewlekłej skóry, jaką jest trądzik różowaty, u pacjenta $\mathrm{w}$ podeszłym wieku możliwe jest dodatkowe pojawienie się nużycy i nadkażenie innymi patogenami - $w$ tym przypadku stwierdzono kandydozę skóry gładkiej.

Etiologia trądziku różowatego jest złożona i niewystarczająco poznana, co potwierdza także nasze badanie.

Istotnym czynnikiem wpływającym na przebieg trądziku różowatego jest edukowanie pacjentów w zakresie odpowiedniej pielęgnacji skóry i unikania czynników, które mogą prowadzić do zaostrzeń (ostre przyprawy, słońce, znaczne różnice temperatur, alkohol) [18]. Duże znaczenie może mieć także edukacja pacjentów oraz lekarzy podstawowej opieki zdrowotnej na temat stosowania miejscowych glikokortykosteroidów i potencjalnych powikłań takiego leczenia. 


\section{CONFLICT OF INTEREST}

The authors declare no conflict of interest.

\section{KONFLIKT INTERESÓW}

Autorzy nie zgłaszają konfliktu interesów.

\section{References \\ Piśmiennictwo}

1. Jabłońska S., Majewski S.: Choroby skóry i choroby przenoszone drogą płciową. PZWL, Warsaw, 2017.

2. Tan J., Schöfer H., Araviiskaia E., Audibert F., Kerrouche N., Berg M.: Prevalence of rosacea in the general population of Germany and Russia - the RISE study. J Eur Acad Dermatol Venereol 2016, 30, 428-434.

3. Moustafa F., Hopkinson D., Huang K.E., Feldman S.: Prevalence of rosacea in community settings. J Cutan Med Surg 2015, 19, 149-152.

4. Kaszuba A., Adamski Z.: Dermatologia. Poradnik lekarza praktyka. Czelej, Lublin, 2012.

5. Hsu C.K., Hsu M.M.L., Lee J.Y.Y.: Demodicosis: a clinicopathological study. J Am Acad Dermatol 2009, 60, 453-462.

6. Kuhnigk T., Borst E.M., Breunig A., König H., Collins M.D., Hutson R.A., et al.: Bacillus oleronius sp.nov., a member of the hindgut flora of the termite Reticulitermes santonensis (Feytaud). Can J Microbiol 1995, 41, 699-706.

7. O'Reilly N., Menezes N., Kavanagh K.: Positive correlation between serum immunoreactivity to Demodex-associated Bacillus proteins and erythematotelangiectatic rosacea. Br J Dermatol 2012, 167, 1032-1036.

8. Jakubowicz O., Luczkowska M., Żaba R., Adamski Z.: Tinea cutis glabrae: causes of diagnostic challenge. Adv Dermatol Allergol 2014, 31, 421-424.

9. Dutta B., Rasul E.S., Boro B.: Clinico-epidemiological study of tinea incognito with microbiological correlation. Indian J Dermatol Venerol Leprol 2017, 83, 326-331.

10. Hengge U.R., Ruzicka T., Schwartz R.A., Cork M.J.: Adverse effects of topical glucocorticosteroids. J Am Acad Dermatol 2006, 54, 1-15.

11. Nicola A., Laura A., Natalia A., Monica P.: A 20-year survey of tinea faciei. Mycoses 2010, 53, 504-508.

12. Gorani A., Schiera A., Oriani A.: Case report. Rosacea-like tinea incognito. Mycoses 2002, 45, 135-137.

13. Forton F.M.N., De Maertelaer V.: Papulopustular rosacea and rosacea-like demodicosis: two phenotypes of the same disease? J Eur Acad Dermatol Venereol 2018, 32, 1011-1016.

14. Daning L., Dinguo Z., Wenwei S., Peihong J.: Extensive skin candidosis in an adult: effective treatment with itraconazole. Mycoses 1998, 41, 219-221.

15. Alteras I., Sandback M., David M., Segal R.: 15-year survey of tinea faciei in the adult. Dermatologica 1988, 177, 65-69.

16. Krajewska-Kułak E., Moss E., Lukaszuk C., Niczyporuk W., Bartoszewicz M., Roszkowska I.: Common difficulties in the diagnosis and therapy of tinea in patients diagnosed in Dermatology Hospital in the years 1981-2000. Kor J Med Mycol 2003, 8, 103-109.

17. Sikorska M., Nowicki R.: Mycosis of smooth skin treated as contact allergy. Alergol Pol 2017, 3, 126-130.

18. Zegarska B., Placek W.: Zasady pielęgnacji skóry w przebiegu trądziku różowatego. Dermatol Estet 2004, 5, 281-285.

Received: 29.11 .2018

Accepted: 14.05 .2019

Otrzymano: 29.11.2018 r.

Zaakceptowano: $14.05 .2019 \mathrm{r}$.

How to cite this article

Łańczak A.M., Spałek M., Kubisiak-Rzepczyk H., Jenerowicz D., Bowszyc-Dmochowska M., Adamski Z.: Candidiasis and demodicosis of facial skin imitating exacerbation of rosacea. Dermatol Rev/Przegl Dermatol 2019, 106, 411-416. DOI: https://doi.org/10.5114/dr.2019.88259 